Seminars, Conferences, Addresses

\title{
Imäm al Tirmidhi and the Modern Age
}

An International Conference

Tashkent, Uzbekistan, USSR

Safar 24-27, 14H/September 14-17, 1990

The Muslim Religious Board for Central Asia and Kazakhstan organized an international conference in Tashkent, the capital city of Uzbekistan, in connection with the observances of the twelfth centenary of the birth of Imām Abũ 'İsā Muḥammad Ibn 'Īsā al Tirmidhī, a native son. The conference was attended by scholars from the Soviet Union and nearly 100 delegates from overseas.

The keynote address, which was also the conference's theme, was delivered 
by the Board's Chairman Mufti Muhammad Sadyq Muhammad Yusuf. He presented a detailed account of the Imām's work, especially the well-known book Al Jämi' al Sahihh, and its impact on the contemporary world.

The scholars stressed the need for greater attention to research and study of the Sunnah of the Prophet Muhammad (SAAS). They also adopted a number of recommendations, including a call for greater attention to research on the hadith in order to facilitate its effective application in the everyday lives of Muslims. This, it was observed, would contribute toward the assertion and developoment of Islamic values throughout the ummah.

The conference recommend that:

- The Board should seek the cooperation of Islamic research organizations overseas in establishing an institute for the study and research on the hadith and on the lives of the muhaddithün.

- Regular meetings should be held in Uzbekistan to further develop and enrich the science of hadith. It was also recommended to institute an award for those who excel in the knowledge of the hadith.

- The Board should seek the cooperation of specialized agencies in the Islamic world to enhance its publishing activities and organize translations of the great works done on hadith in the region.

- A university should be established in honor of Imām Tirmidhī.

The conference instituted a fourteen-member international board to organize a fund-raising campaign to collect money for a university and for the restoration of masâjid and other Islamic institutions in the Soviet Union.

Mufti M.Y.M. Yusuf

Chairman, Muslim Religious Board for Central Asia and Kazakhstan Tashkent, Uzbekistan, USSR 